Article

\title{
The Spiritual Dimensions of the Permaculture Movement in Cuba ${ }^{\dagger}$
}

\author{
Rose T. Caraway \\ Department of Philosophy and Religious Studies, Iowa State University, Ames, IA 50011, USA; \\ rcaraway@iastate.edu; Tel.: +1-515-294-3638 \\ + A previous version of this article was presented at the American Academy of Religion Annual Conference \\ in 2015.
}

Received: 17 September 2018; Accepted: 1 November 2018; Published: 3 November 2018

check for updates

\begin{abstract}
Following the collapse of the Soviet Bloc, Cuba experienced an acute economic crisis in the 1990s known as the "Special Period". This crisis challenged not only the state's ability to provide for Cubans' material needs, but also the moral vision of creating a "New Human" within the Revolution's political framework. During the Special Period, a variety of new religious and civil society movements emerged to meet both the material and spiritual needs of Cubans. Permaculture, a holistic design system that arrived from Australia in 1993, promotes more harmonious relationships between human beings and nature through a set of three ethical principles: (1) Care for the Earth; (2) Care for People; and (3) Sharing Resources. Within the Cuban context, the growing permaculture movement is part of a larger set of religious and civil society revivals since the fall of the Soviet Bloc. Using qualitative fieldwork, this paper argues that permaculture is functioning as a religious-like movement in Cuba because it provides both spiritual and material benefits to individuals through networks of mutual aid and social solidarity. The permaculture movement also provides flexibility for individual perspectives about nature as sacred and having intrinsic value apart from usefulness to humans.
\end{abstract}

Keywords: Cuba; permaculture; nature spirituality; religion and politics; theories of religion

\section{Introduction}

Prior to the collapse of the Soviet Bloc in 1991, Cuba utilized a highly centralized, conventional model of agricultural production on large-scale nationalized farms. This model relied heavily upon high levels of imported agrochemical products, monocultural production systems, and a concentration of farmers in cities or rural towns (Funes-Monzote 2010, p. 206). When the Soviet Union fell and imports of subsidized material goods were suddenly no longer available, the conventional model of agriculture that Cuba had relied upon was no longer sustainable. Through various outreach and educational programs, the state began to encourage alternative forms of agricultural production, sustainable development projects, and the creation of on-site farms and gardens in residential and educational areas. In spite of these efforts, however, "the success of these strategies has been muted by a variety of factors, including the difficulty of adapting specialized large-scale agriculture to new practices, a lack of monetary resources and materials to enact these solutions, and a small workforce in the countryside" (Funes-Monzote 2010, p. 215). As the Cuban government has faced a decreasing ability to provide for Cubans' basic needs, a wide variety of civil society networks, including religious organizations, have emerged in order to address the spiritual and material needs of Cuban citizens (Crahan 2015, p. 92).

It is within this historical framework that we can analyze the arrival of permaculture to Cuba in 1993 from a "solidarity brigade" of volunteers from Australia and New Zealand (Cruz et al. 2006, 
p. 7). The term permaculture itself is challenging to define precisely because of its holistic nature. Speaking broadly, it is a design system rooted within ecology that has historically "focused on land and nature stewardship as both a source for and an application of ethical design principles", and these principles are now being applied to a wider range of domains dealing with energy resources and the development of human communities (Holmgren 2002, p. xix). As a holistic design system, the ethics and principles of permaculture are built upon an approach that embraces systems-thinking. This approach views elements within a particular system (water, sunlight, soil, animals) as integrated, where (1) each element can perform many functions; and (2) each function is supported by many different elements (Holmgren 2002, p. 155). Within individual ecosystems, a variety of different relationships between elements can occur. These range from predatory and parasitic relationships on the one hand, to symbiotic relationships on the other, where "organisms become so interdependent that they cannot live without one another" (Holmgren 2002, p. 155).

There are three main ethical principles of permaculture (Care for the Earth, Care for People, and Sharing Resources through redistribution of surplus), as well as a set of twelve design principles that include observing and interacting, catching and storing energy, the use of renewable resources, valuing diversity, and using edges and valuing the marginal (Holmgren 2002). These ethical and design principles overlap with non-institutionalized spiritual worldviews and practices, and in the Cuban context, institutionalized religious belief. As Taylor (2010, p. 157) notes, permaculture is tied to some "countercultural branches of the global environmentalist milieu", and while the movement is grounded in ecology, it can also draw upon religious-resembling phenomena, such as animistic spirituality, rituals, and the recognition that nonmaterial energies or spirits animate life forms.

In the Cuban context, the cambio de mentalidad, or "change in mentality", points to an internal process of transformation, where individuals fundamentally shift their way of thinking and learn to live in a new way with one another and with the Earth. This shift in perception echoes (Leopold [1949] 1987) concept of the land ethic, which involves a perceptual shift in how individuals see themselves in relationship to the natural world. For Leopold, "the land ethic changes the role of Homo sapiens from conqueror of the land community to plain member and citizen of it" (Leopold [1949] (1987, p. 204), and it "enlarges the boundaries of the community to include soils, waters, plants, and animals, or collectively: the land" (Leopold [1949] (1987, p. 204). Taylor (2010, p. 9) argues that we can analyze Leopold's land ethic as a form of what he calls dark green religion, where "nature is sacred, has intrinsic value, and is therefore due reverent care". Despite this appeal to dark green religion that Taylor argues is inconsistent with green religion found in traditional religions, in practice these themes have united Cuban permaculturalists with different backgrounds and relationships to institutionalized religions.

Through an analysis of qualitative interviews with Cuban permaculture activists, this paper explores the connections between spirituality and permaculture. According to Taylor (2010, p. 3), ecological movements that encourage deep, affective connections to the natural world can be understood as spiritual, because spirituality involves "gaining a proper understanding of one's place in the cosmos". For Taylor, humans need to recognize that they are a part of creation rather than being apart from it. This perspective challenges assumptions about human uniqueness as compared to nature that inform modern agricultural systems. Taylor (2010, p. 4) further argues that "unless one considers belief in divine beings or forces to be essential to a definition of religion, most contemporary spirituality can easily be considered religious". This type of religion, which he calls "dark green religion" (in which nature is sacred, has intrinsic value, and is therefore due reverent care) is often in tension with "green religion", which is found in world religions and posits that environmentally friendly behavior is a religious obligation (Taylor 2010, p. 10). Looking at the ideological, material, and cultural context of Cuba illustrates that permaculture allows space for both ways of thinking (dark green religion and green religion), through a flexibility in perspectives about nature as sacred.

The ethics and principles of permaculture seek to break down assumptions regarding the separateness of humans from other animals and from the natural world in which they are embedded. Although the recognition of limits to consumption of earth's resources is a part of global permaculture 
ethics, this is particularly emphasized in Cuba because individuals have, out of necessity, learned creative ways to inventar (invent) solutions to problems with access to few material resources. Gabriel and Leidis, for example, are Baptist permaculture activists in the city of Santiago who work with an ecumenical center, and they helped explain the importance of these themes. Within the Cuban context, the third principle of permaculture (sharing resources) is crucial because material resources are frequently lacking. Leidis stated that "this is a country where the resources don't cover very much. But resources can also be our work; that is to say, 'We're going to dedicate two hours of our day'" (personal interview, 26 March 2016).

Permaculture activists spend time working on each other's sites, and they share both seeds and experience-based knowledge of how to implement the principles and ethics of the movement. Seeds are neither patented in Cuba nor tied to corporations, so for permaculturalists the sharing of seeds with one another reflects the cultural value of social solidarity rather than producing wealth. Cuban permaculture emphasizes moral and ethical messages tied to a critique of consumption and highlights the need for sharing and redistribution of resources. This critique of consumption within Cuban permaculture has also been shaped by a political context that is critical of global capitalism.

Within Cuban permaculture, there is a particular emphasis on mutually beneficial relationships, such as cooperation rather than competition, and redistribution of resources. This too has been shaped by Cuba's material context, but it also rests upon an ethical and spiritual concept that seeks to reorient how human beings view themselves in relationship to the natural environment. Rather than seeing themselves as somehow separate from or superior to nature, Cuban permaculture encourages human beings to see themselves as part of a larger web of relationships within nature.

I asked Juan Manuel, a promotor of permaculture in the Los Pinos neighborhood outside of Havana, what he thought was one of the most important lessons that he learned from the movement; he highlighted two lessons. The first was the idea that one had to respect life because everything was integrated holistically; "every little animal has its own value". The second lesson was that "we have to change the social and ecological culture of people ... because we are really doing damage to the planet" (personal communication, 9 March 2016). Cuban permaculture activists frequently emphasized that they saw themselves as "one more element" within their systems as Homo sapiens, and many expressed deeply held affective bonds with the plants and animals within their permaculture systems. Activists also highlighted the idea that permaculture wasn't just about learning to grow organic food; it was about the importance of interdependent relationships between human beings as well as humans and other parts of the natural world.

Besides being spiritual, permaculture in Cuba functions as a religious-like movement that is part of a larger set of religious revivals and social change in civil society since the fall of the Soviet Bloc. As the government's capacity to respond to people's basic needs deteriorated, individuals turned to religion as a source of comfort (Crahan 2009, p. 17). These new religious groups not only provided material comfort, but they also addressed spiritual needs. According to Crahan (2009), the sociologist Laureana Cruz attributed the recent religious revivals to the fact that the fall of the socialist bloc meant that the world that many Cubans trusted no longer existed. In other words, the post-Soviet rise in religious revivals involves more than a response to material scarcity. The Cuban Revolution did not just involve nationalizing land and businesses; at its root, it has been tied to a moral vision within a scientific atheist framework that is now secular in nature. Thus, when the moral vision to create a "New Human" within Cuban society was challenged with the collapse of the Soviet Bloc, a variety of religious and civil society organizations arose to help Cubans (particularly young Cubans) who were seeking existential as well as material answers.

Permaculture in Cuba also functions like other religious movements in Cuba, because it provides spiritual as well as material benefits through networks of mutual aid and social solidarity. The Antonio Núñez Jiménez Foundation for Nature and Man (hereafter "FANJ"), a non-governmental organization established in 1994, has been at the forefront of efforts to promote permaculture across the island through a network of local level and national leaders. When founding FANJ, Antonio Núñez Jiménez 
felt that the ethical vision of harmonious relationships between human beings and nature would serve as the backbone of the philosophical foundation for the NGO that took his name. Best known for his epic journey from the jungles of the Amazon to Cuba in a dugout canoe (which now sits in the FANJ museum in Sancti Spíritus), Jiménez declared in 1997 that permaculture could play a key role in the development of a "culture of nature" in Cuba. In this "culture of nature", human civilization is designed to be in harmony with its natural surroundings (Birnbaum and Fox 2014, p. 54). FANJ spread permaculture with these ideas through a highly contextualized three-part method, creating networks that united permaculture activists who have a wide variety of personal backgrounds, identities, and relationships to institutionalized religions.

\section{Methodology}

During March and April of 2016, I visited 19 different permaculture systems in three different Cuban provinces: Havana, Sancti Spíritus, and Santiago de Cuba. FANJ provided contact information for permaculture activists, and I used it to select these sites. The Cuban permaculture movement is not directly tied to the government, although the state has promoted agroecological methods of food production. The movement is, however, directly tied to FANJ and networks of permaculture activists and promotors across the island. From a legal perspective, all organizations in Cuba (including civil society and religious organizations) must be under the supervision of state agencies (Crahan 2015, p. 91), and this would include FANJ.

According to its website, FANJ has five programs dedicated to environmental education and the promotion of sustainability: (1) Geohistory and Political Ecology; (2) Heritage Preservation; (3) Sustainable Localities; (4) Nature and Community; and (5) Responsible Economies and Consumption. The third area (Sustainable Localities) is explicitly dedicated to the "contribution and the creation of sustainable localities from citizenship action and the promotion and implementation of permaculture". FANJ also has "delegates" within seven provinces that help organize the training of local leaders and activists. FANJ has played a critical role in the outreach and expansion of permaculture in Cuba, because it uses a participatory form of learning tied to the farmer-to-farmer sustainable agriculture movement brought in from Mexico in the early 1990s (Holt-Giménez 2006). Villi, a permaculture activist in Santiago, referred to this method as " $80 \%$ practice, $20 \%$ theory" during an interview on 3 April 2016. In other words, the promotion of permaculture in Cuba focuses on "learning by doing", rather than focusing on permaculture principles in the abstract. Cuban permaculture activists also worked on each other's permaculture systems regularly.

When I visited permaculture systems, I conducted analysis using two methods: (1) observation and (2) qualitative interviews. In the observational portion of the research, I noted the name of individual systems; the types of permaculture strategies and principles used; the varieties of specific fruits, vegetables, and medicinal plants grown within the system; water collection and filtration strategies; and the use of alternative energy sources such as solar dryers, ecological "dry" bathrooms, and ecological kitchens. Cuban permaculture activists referred to their sites as "systems" rather than farms because permaculture is a holistic design system that is organized around five "zones" or concentric areas that relate to human intensity of use. Zone 1 represents the house, while zone 5 represents a "wilderness" area that relies upon little to no human input (Holmgren 2002, p. 139).

In addition to observation of individual permaculture systems, I conducted qualitative interviews using semi-structured research questions with thirty-five permaculture activists in March and April of 2016. Qualitative interviews lasted approximately an hour and a half in length. In addition to asking participants questions about how they first became affiliated with FANJ and the nature of their participation in that NGO, I also focused on participants' individual interpretations of the three main ethical principles of permaculture: (1) Care for the Earth; (2) Care for People; and (3) Redistribution of Surplus through the sharing of resources. What did these ethical principles mean to them within the Cuban context? Upon returning to the United States, I coded the qualitative interviews using sets of key terms in order to find common patterns across the interviews. During a particular interview, for 
example, if the participant was describing the specific methods that FANJ used in order to promote permaculture (workshops, demonstrations), I assigned the code "FANJ organization/outreach".

My informants in this Cuban case study came from a wide variety of personal backgrounds, geographical locations, and walks of life. Within the informed consent process, informants were provided with the option of choosing to remain anonymous using pseudonyms; however, all participants in this study voluntarily selected the option of having their real names used in the study. ${ }^{1}$

The majority of informants in Santiago de Cuba self-identified as Baptists affiliated with the Eastern Baptist Convention. Others, such as Edinson in Sancti Spíritus, were tied to Los Pinos Nuevos (The New Pines) Evangelical Seminary. Some informants did not identify with any religion in particular; Isabel in the Los Pinos neighborhood, for example, is not religious but she comes from an Adventist family. In spite of these different backgrounds, permaculture activists frequently emphasized that they felt that they were part of a larger "family" of individuals to whom they could turn, during both good moments and moments of great difficulty. After the fall of the Soviet Bloc, Cubans experienced moments of great difficulty during an acute economic crisis known as the "Special Period".

\section{The Cuban Special Period and the Arrival of Permaculture}

In the summer of 1990, Fidel Castro announced the implementation of the Periodo Especial (Special Period), or a series of contingency plans involving austerity measures and rationing schedules in order to adjust to the loss of trading partners from the former socialist bloc. The "Special Period", as Reguant (2009, p. 1) notes, was not just an historical construct; it was also a "defining category of experience" during the 1990s that followed Cuba's loss of Soviet trade and support. The Council of Mutual Economic Assistance (CMEA) had previously accounted for nearly 85 percent of all of Cuba's trade, and Soviet oil and petroleum by-products had accounted for approximately 90 percent of Cuba's energy needs (Pérez 2015, pp. 304-5). The effects of this tremendous loss of material resources from the former Soviet Union were broad reaching and devastating. Pérez $(2015$, p. 306) stated that during the Special Period, "life settled into a grim and unremitting cycle of scarcity, in which shortage beget shortage and where some of the most basic daily needs of daily life in their more ordinary and commonplace form could be satisfied only by Herculean efforts".

There developed a set of quotidian sayings among Cubans during this period: resolver (to resolve) and inventar (to invent), which basically refers to pursuing whatever is necessary to get by on a daily basis, often through incredibly creative means (Pérez 2015, p. 308). Notably, these phrases have not disappeared from Cuban colloquial Spanish: I have been traveling to Cuba for more than fourteen years pursuing academic research, and I still hear these phrases daily when I visit. This underscores the fact that the Periodo Especial was a distinctive marker for the Cuban people, not only in terms of the loss of material resources, but in terms of culture and morality. As Pérez $(2015$, p. 310) notes, "new fault lines appeared on the moral topography of Cuban daily life and acted to reconfigure the normative terms by which Cubans entered the twenty-first century".

The Período Especial also set in motion the search for alternative methods of food production, in light of the sudden loss of petroleum-based pesticides and fertilizers. Prior to the collapse of the Soviet Bloc, Cuba had relied upon a highly centralized, industrial agricultural model using monocrop cultivation on large plots of land that had previously been nationalized through the Agrarian Reform Laws of 1959 and 1963 (Koont 2015, p. 399). This industrialized model caused several issues, both economic and environmental. First, the model relied exclusively upon imports from the Soviet Union and Eastern Bloc, which became unsustainable during the Special Period. Second, Cuba's industrialized model of agricultural production caused increasing damage to the soil (Koont 2015, p. 399).

As early as 1987, then Defense Minister Raúl Castro suggested the possibility of generalizing food cultivation without the use of petrochemicals, and armed forces facilities began installing organipónicos 
(raised beds using organic material) to grow vegetable gardens (Koont 2015, p. 400). During the Special Period, the state, the National Association of Small Farmers (ANAP) and Cuban scientists "promoted and implemented a series of measures to maintain agricultural production in the absence of imported chemicals and machine parts. These included the recovery of traditional farming practices with low levels of external inputs, as well as the use of ecological methods developed by Cuban researchers" (Sosa et al. 2013, p. 23). The production of vegetables initially dropped dramatically between 1988 and 1994 but rebounded significantly after 2007 thanks to previous land decentralization efforts and the creation of 2,600 new small urban and suburban farms since the 1990s (Altieri and Funes-Monzote 2012).

The state also began to encourage individuals to grow food individually within local plot gardens. Sánchez, a retired army officer who converted a vacant lot into a permaculture "hotspot" for the Sevillano neighborhood outside of Havana (Birnbaum and Fox 2014, p. 12), told me that during the Special Period there was a nationwide call by Fidel Castro to urge people to plant food in their spaces "because those were hard times that arrived". Sánchez stated that "I began to plant in the little plot that I had, but the form that I used was from traditional agriculture" (personal communication, 11 March 2016). He began to plant bananas, squash, yucca, and sweet potato, but he had to wait a year to harvest and eat those things. FANJ approached Sánchez when they saw that he had a productive space, but he initially declined to get involved with the permaculture movement because at the time he had responsibilities as a delegate with the Poder Popular. The Poder Popular are Neighborhood Popular Councils mandated by the Cuban National Assembly. Residents from each neighborhood ward elect a delegate to represent their local concerns and issues to the Councils (Scarpaci 2002, p. 179).

The results of the Cuban government's efforts to promote more ecological methods of farming since the Special Period indicate both strengths and weaknesses. In terms of strengths, there have been notable successes with root crop production, other vegetables, fruits, eggs, and seafood (Altieri and Funes-Monzote 2012). Other food items, such as cooking oil, legumes, corn and soybeans, have much higher import rates than sugar crops, fruits, and vegetables. In addition, despite widespread government efforts to promote agroecological methods of farming, "interest persists among some leaders in high external inputs with sophisticated and expensive technological packages" (Altieri and Funes-Monzote 2012). These programs are focused on "maximization" of crop and livestock production and an insistence upon returning to monocrop agricultural methods, which is running up against the efforts of permaculture activists to rely upon fewer external inputs.

In addition to a focus on organic farming and avoiding the use of chemical pesticides and fertilizers, permaculture also emphasizes the need for humans to fundamentally reevaluate how they see themselves in relationship to the natural world in which they are embedded. FANJ is at the forefront of these efforts, and they are networking with other organizations in Cuban civil society to encourage this transformation.

\section{FANJ and the Expansion of Permaculture in Cuba}

Since the Special Period, FANJ has played a critical role in the expansion of permaculture in Cuba through a network of promoters and facilitators who are working within their local communities. Juan Manuel, who serves as a national promoter of permaculture through FANJ, stated in an interview on 9 March 2016 that "I think that there wouldn't be permaculture groups in the country if the Foundation hadn't had so many permaculture design courses". FANJ utilizes a "people-to-people" method of outreach and promotion that is based upon the Campesino a Campesino (CAC) movement, a grassroots agroecology social movement imported from Mexico during the Special Period (Holt-Giménez 2006, p. 32). The Cuban National Association of Small Farmers (ANAP) utilized the CAC methodology to promote a transition to agroecological methods of food production following the collapse of the Soviet Bloc. When FANJ was formed in 1994, it took the permaculture movement that was imported from Australia and combined it with the CAC methodology and the work of ANAP to promote permaculture across the island. 
The process of incorporating permaculture into the Cuban context started within the Institutio Cubano de Investigaciones y Orientación de la Demanda Interna, where Australian volunteers constructed a permaculture demonstration site on the rooftop to provide vegetables for the workers of the Instituto. The Instituto would eventually disappear, and in 1994 Antonio Núñez Jiménez founded FANJ with the hope of promoting a "culture of nature" within Cuban society (Stricker 2007). The staff "took up permaculture as part of their organizational mission and philosophy", and FANJ began offering workshops and courses to individuals in the Havana area who were already practicing urban farming (Williams 2017, p. 40).

Several international organizations and NGOs, as well as Cuban organizations, have collaborated with FANJ: the German Protestant organization, Bread for the World; Oxfam International; the Cuban Ministry of Culture; the Cuban Ministry of Agriculture; the Federation of Cuban Women; and the Cuban Counsel of Churches, among others (Cruz et al. 2006, p. 8). Thus, FANJ has connections with both state organizations as well as international organizations, and it receives material aid from international NGOs for its projects. Cuban permaculture activists can in turn receive aid from FANJ; the large water collection tanks that I saw in several permaculture systems, for example, were from FANJ.

FANJ has been described as a non-governmental organization in the literature (Williams 2017). However, as Margaret Crahan notes, all organizations in Cuba, including citizen organizations, must be under the supervision of government agencies. There is wide range of organizations in Cuban civil society that operate along a continuum, with some groups that have a high degree of autonomy (Crahan 2015, p. 91). During qualitative interviews, permaculture activists who worked with FANJ frequently mentioned the material support from the international NGO Bread for the World, but the historical relationship between FANJ and the state was not highlighted. The founder of FANJ, Antonio Núñez Jiménez, was granted permission by Fidel Castro to start his own organization during the Special Period because (1) the two had developed a relationship of trust; and (2) the state began permitting Cuban civil society organizations to help with social issues (Johnson 2017). Organizations like FANJ are financially sponsored "by international NGOs from countries like Canada, Australia, Spain, and Italy, but are part of the Cuban state, and they uphold the principles of the Cuban socialist Revolution" (Gold 2015, p. 118).

Oscar, who has a permaculture system in Santiago de Cuba, stated that although the government had "talked a lot about agroecology", the interest in permaculture "had not taken hold much at the level of the government". Some individuals from the government had visited the system, and Oscar explained to them how permaculture functioned (personal communication, 30 March 2016). This was an interesting observation, because Oscar made a distinction between agroecology (the application of the ecological sciences to agricultural production) and permaculture. Notably, Oscar was not the only permaculture activist to do this; my interviews with other activists in Santiago de Cuba revealed similar themes. Williams (2017) found during fieldwork that one permaculture promoter, who had learned about agroecology from the local office of the National Association of Small Farmers (ANAP), claimed that they saw "in permaculture more opportunities than in agroecology. Agroecology gives you the opportunity to conserve soil, you see? It teaches you to conserve soil and seeds following the campesino tradition. But permaculture takes you above and beyond" (Williams 2017, p. 39). With the "above and beyond" statement, this activist was arguing that permaculture was a philosophy and a "way of life". This connects to the larger argument of this paper, which is that permaculture can be analyzed as a religious movement that shapes how people see and interact with the world.

FANJ's method of introducing and promoting permaculture involves a highly contextualized process that works directly through community groups at the grassroots level. El Ranchón is an organipónico located in the Sancti Spíritus province in central Cuba that incorporates permaculture ethics and practice into its system. Workers plant medicinal species (lemongrass, citronella) at the front of rows, which either attract or repel insects, depending upon the species. Local food from El Ranchón is provided to the workers, and produce is also sold to the surrounding neighborhoods through the market that they have operating directly on the site. This illustrates the theme of social engagement 
within Cuban permaculture ethics and practice. According to Roger, who helps run El Ranchón, he and his wife left their careers in engineering and "traditional agriculture" in 1994 during the heart of the Periodo Especial. Although their physician could not directly determine the cause of debilitating headaches and two miscarriages, Roger attributed these conditions to their significant exposure to insecticides, fungicides, bactericides, and herbicides (personal communication, 18 March 2016).

Roger and his wife decided to move into agroecological methods of growing food within the urban garden movement, and in the year 2000 he and 74 other Cubans received an introduction to permaculture when FANJ visited the province. Roger claimed that the experience "changed everything that they learned at the university", and he became motivated to promote permaculture. In 2001 he helped form a group called Grupo de Sustentabilidad Urbana (Urban Sustainability Group), which initially began providing permaculture activities for acquaintances and then expanded to a grassroots permaculture fair that was organized "neighborhood by neighborhood". In 2002, FANJ invited the group to take the free permaculture course that they offered (personal communication, 18 March 2016).

The method of outreach and promotion that Roger described is part of the unique three-part method that FANJ developed in the 1990s. The first step is reaching out to individuals who might be interested in permaculture through what is called a taller motivocional (motivational workshop). This workshop, which is a basic introduction to permaculture, can be organized by autonomous individuals and groups; in other words, FANJ does not have to be the organization that facilitates every taller, although facilitators who work with FANJ often do. A community member could approach another community member who might be selling plants from their patio, for example. This hypothetical scenario is similar to the case of Isabel, one of the early pioneers of the permaculture movement in the Los Pinos neighborhood outside of Havana. Two workers from FANJ approached Isabel in 1993 during the Special Period because they were aware that she sold plants on her patio. They discussed with her the possibility of "capturing a group of people and giving them an introduction to permaculture, a beginning, a tallercito" (little workshop) (personal communication, 9 March 2016)

The second step in the Cuban process is the organization of the taller de acercamiento, or the "approaching workshop". This workshop is more in-depth than the initial taller, where participants learn about the main ethical ideas of permaculture, the history of the movement, and the various design principles. This workshop's function, which brings in the experiential learning methods from the Farmer to Farmer (Movimiento Campesino a Campesino, or MCAC), is designed to encourage participants to begin working within their own permaculture design systems, even though they haven't yet passed the permaculture design course.

The third step in the Cuban process is the permaculture design course offered through FANJ. Juan Manuel explained that even though FANJ is technically a non-governmental organization with a central address in Havana, it actually functions as a network of 24 national permaculture groups that help facilitate communication between individual coordinators who work in different provinces and geographical regions across the island. Each of these permaculture groups "has characteristics that are very autonomous", and this autonomy enables the individual groups to respond to highly specific and contextualized needs within local communities (personal communication, 9 March 2016).

According to Leticia, this three-step method is what makes permaculture in Cuba distinctive. The taller de acercamiento can come directly from within individual communities themselves, within the locations where people live. This way, one can see how individuals within the taller de acercamiento are "comprehending, are changing their mentality" through experiential learning techniques (personal communication, 3 May 2016). This "cambio de mentalidad" (change of mentality) involves re-imagining how human beings see themselves in relationship to not only other humans, but to the natural world in which they are embedded. It also involves a shift towards more experiential-based learning techniques, where individuals incorporate knowledge about how ecosystems function into their daily lives. As Gibson-Graham and Roelvink note, "in our new geological epoch of human-induced climate change, the Anthropocene, it has become increasingly clear to us that the more-than-human world is fundamentally implicated in the way we live our lives. We humans are neither masters nor caretakers 
of the environment and other species; the more-than-human world is an active participant in diverse economies" (Gibson-Graham and Roelvink 2011, p. 32).

When Sánchez completed his responsibilities in 2007, he took the permaculture course offered by FANJ. Sánchez had a wide variety of elements in his system: fruits, fruit trees, vegetables, medicinal plants, chickens, a dry ecological bathroom, a pond for fish, and a water filtration system. Throughout his permaculture system, both at the front of his house and within the system, Sánchez had colorful signs promoting some of the ethics and values of permaculture. One of the signs said, "Fundamental ethical principles of permaculture: Care for the Earth, that is to say, the Planet, with its animate and inanimate elements. Care for People. Share the surplus. Violence interrupts cooperation and it's never an opportunity" (personal communication, 11 March 2016).

Signs that promote individual permaculture systems are another way that FANJ has been successful in the promotion of permaculture. Juan Manuel and Leticia's initial curiosity about the movement was sparked when they were passing by a sign one day that said, "We do permaculture here". They asked Isabel, one of the early pioneers of the permaculture movement in the area, about the sign. Isabel then encouraged them to participate in a taller motivocional. Leticia stated that after participating in the taller motivocional, they realized that the patients at the community health center where they worked could grow vegetables without chemicals. That possibility really "hooked her" (enganchar) the most because she was concerned about the rehabilitation of her patients (personal communication, 3 May 2016). This description of being "hooked" by permaculture was noteworthy in light of the interview with Isabel; Isabel argued that promoting permaculture was similar to what religious missionaries do: “It's like the religious people. The religious people go preaching their religion all around the world and from house to house. We say that there are ten people that close the door, but one that opens it. They don't tire of preaching. Why would we, who say that we love nature, get tired?" (personal communication, 3 March 2016).

FANJ is not a religious organization, but it is part of a larger group of civil society networks that have emerged in the aftermath of the fall of the Soviet Union and the Special Period. At the local level, networking between religious organizations, human rights groups, youth groups, and community groups has increased significantly since the 1990s, which suggests that "associationalism in Cuba is today stronger than in any period since the 1960s" (Crahan 2015, p. 93). FANJ can be analyzed as part of a larger post-Soviet revival in civil society and religious organizations for several reasons.

FANJ was founded during the heart of the economic crisis that resulted from the collapse of the Soviet Bloc, when Cubans were forced out of necessity to come up with creative ways growing food, recycling, using renewable resources, and caring for themselves and their families. The economic crisis, in combination with the larger socio-economic changes that occurred between state and civil society groups, provided fertile ground for the expansion of permaculture and other spiritually engaged movements. As a holistic movement that addresses spiritual as well as material concerns, permaculture arrived in Cuba in the early 1990s and was able to spread because of the larger changes that were occurring in civil society at the time.

\section{The Spiritual Dimensions of Cuban Permaculture: Religion, Spiritual Needs, and Social Change in Post-Soviet Cuba}

During fieldwork in March and April of 2016, I visited several organipónicos that were also utilizing permaculture methods and principles. On the 28 April 2016 I interviewed Edith, who has a background as a professor of biology and works at the "Linda Flor" organipónico in the province of Sancti Spíritus. During the Special Period, her school was moved to the countryside because there was no gasoline available for transportation. Edith had a small child at the time and couldn't move locations, so she began to pursue other work after the government decided to create an organipónico of flowers in her area.

According to Edith, this was done because the Cuban state recognized that people needed not only sustenance from food, but also sustenance for their "souls" due to the widespread issues of depression 
at the time: "In 1994 I came here because they had begun creating those organipónico movements with the objective of satisfying the nutrition needs of the population during that moment of crisis, of food. And so they began to develop urban agriculture with those movements. The First Secretary decided to create an organipónico of flowers because they needed to motivate the population, to satisfy the food needs, sustenance, but also the soul, because the people were really depressed during those times" (personal communication, 28 April 2016). Edith began working at the flower organipónico in Sancti Spíritus with her father in 1994 during the heart of the Special Period.

After FANJ approached her about becoming involved with permaculture, Edith realized that she began to view herself as "more realized" working within the context of the garden than in the classroom because she could directly see the results of her work for herself, her family, and the surrounding community. Today, the "Linda Flor" permaculture system continues to sell flowers and also serves as a central reference for medicinal plants; they have a working relationship with the local policlinico (community health center) to offer alternative "green" medicine from the medicinal plants grown within the permaculture system. Edith stated that prior to becoming involved with FANJ and permaculture, she didn't have a "consciousness" regarding what it meant to care for the Earth. Through permaculture ethics, however, Edith has come to view the soil as "a living organism". This echoes Holmgren (2002, p. 5) discussion about the first ethical principal of permaculture (Care for the Earth) through the notion of living soil: "In the most grounded sense, Care for the Earth can be taken to mean caring for the living soil as the source of (terrestrial) life and for which we have the greatest responsibility".

Edith's statement about the Cuban state recognizing spiritual needs within the population is illustrative of some larger shifts that have happened since the fall of the Soviet Union. In 1991, the Cuban government eliminated the ban on religious individuals holding positions within the Communist Party. A year later, the Cuban Communist Party adopted a constitutional amendment declaring that Cuba was a secular rather than a scientific atheist state (Crahan 2009, p. 107). There were a number of political and social changes that played a role in this shift, including the encouragement of Fidel Castro in the 1980s to promote strategic alliances between Christians and Marxists (Crahan 2009, p. 104). These political changes opened up spaces for religions to practice more freely and, in some cases, gain official recognition by the state (Kocur 2016, pp. 231-32).

Even with these constitutional changes, however, the revolutionary government "has still tried, largely through executive orders, to limit the autonomy and development of associative organizations" (Crahan 2015, p. 91). In terms of belief within the population, the religious scene in Cuba is an interesting combination of several different elements: on the one hand, recent surveys have indicated that approximately 75 to 85 percent of Cubans believe in the divine (Crahan 2015, p. 90). Heidi, who works with an ecumenical center in Santiago in the promotion of sustainability programs, seemed to echo these statistics when she stated that within the Cuban population, many people believe in "something", whether it's God, multiple Gods, or Lucumí-based traditions such as Santería (personal communication, 28 March 2016). On the other hand, there is an historical precedent for low church attendance due to the weakness of the institutional Catholic Church in Cuba, particularly within rural areas (Crahan 2015, p. 90).

It is helpful to think of post-Soviet Cuban civil society in terms of "an expanding public sphere constituted by an increasing number of minispheres within the country and sustained higher levels of voluntary associational activity" (Crahan 2015, p. 91). This activity "includes not only civic associations and institutions but also informal networks linked horizontally with one another and, at times, vertically to political elites and the state" (Crahan 2015, p. 90). There is also a rather broad spectrum of political attitudes: some groups are in sharp opposition to the state; others are critical of the Castro regime but not necessarily opposed to socialism; and others consist of individuals who work for the state but have heterodox or reformist ideas (Crahan 2015, p. 91). Since the collapse of the Soviet Union and dramatic loss of material aid and resources, the Cuban state has retreated from its role as sole provider of social welfare programs. 
In response to this, a variety of religious and other civil society organizations are stepping in to meet the specific humanitarian needs of local communities. However, this expansion of religious social engagement is not only due to material factors; there are spiritual and psychological needs that are contributing to these changes as well, especially among young Cubans who may not remember the harshest years following the collapse of the Soviet Union. As Crahan (2015) notes, "high levels of anomie and alienation in Cuba, as well as loss of faith in the Revolution by a good number of Cubans, especially young people, have fueled a fairly generalized search for spiritual and psychological consolation through religion" (Crahan 2015, p. 97).

When talking about religious revival in Cuba since the fall of the Soviet Bloc we have to keep several things in mind: (1) there has been an upsurge in church attendance and involvement in recent years (Crahan 2015, p. 96), particularly within the Cuban evangelical movement connected to house churches; (2) there is a long history in Cuba of non-institutionalized religious belief and practice, frequently tied to spiritism and African-derived traditions; and (3) since the Cuban state has retreated from its role as sole provider of social welfare programs, there are a growing number of religious and civil society organizations that are becoming more visible through social engagement programs. I argue that nongovernmental organizations like FANJ have been deeply engaged in Cuban civil society through sustainability initiatives like permaculture.

Multiple factors are contributing to a generalized search for spiritual fulfillment in Cuban society, including feelings of alienation among young people (Crahan 2015, p. 97). This alienation is tied to several economic, political, and cultural issues. One major factor involves long-standing problems with the management of Cuba's economy (Harnecker 2015, p. 50), including the continued use of two currencies, the relationship of the state to an increasing number of independent wage earners, recent layoffs in government jobs, and a highly educated populace that is gravitating towards the tourism industry.

A second issue that helps explain alienation in Cuban society is tied to the vision of the Revolution itself; the 1959 Revolution promoted, through highly affective and emotional language, the transformation of the character of the Cuban people through a vision of the "New Human". This vision sought a "change of consciousness", where individuals would work for moral rather than material incentives (Blum 2011, p. 22). The Cuban government has spent a significant amount of political (and economic) capital in the promotion of this vision since 1959, but the collapse of the Soviet Union posed fundamental challenges to it. When Cuba was importing nearly all of its material goods from the former Soviet Bloc, the state could more easily maintain its status as provider of jobs and social welfare programs for citizens, particularly within professional areas such as education and health care. Since the 1990s, however, the state has been cutting back on social welfare initiatives.

At a more fundamental level, the moral vision for creating the "New Human" within a changing civil society has become even more complex, as international organizations, businesses, and religious groups have expanded their networks in Cuba. If you walk today along "La Rampa", a major thoroughfare leading to the neighborhood of Vedado in Havana, you will see Cuban youth sitting along sidewalks on their cell phones, talking to friends and family through new chat programs. With the rise of new technologies and opportunities abroad, what is the future of this Cuban vision for voluntary work for moral rather than material incentives? Youth in particular are losing faith in this vision and turning to other areas for spiritual and moral fulfillment (Crahan 2015, p. 97). Permaculture activists tied to FANJ are well aware of these recent cultural and economic changes, which explains why they have been reaching out to Cuban youth to encourage them to become involved in permaculture. For activists, permaculture not only offers opportunities to be more self-sufficient in food production; it is a "philosophy of life" tied to a spirituality that embraces caring for the Earth, one's self and one's family, and one's community.

Permaculture has addressed these needs and has functioned like a religious movement by providing (1) care and support through networks of social solidarity and (2) a cambio de mentalidad (change of mentality), where individuals embrace a love of the Earth and recognize their dependence 
upon it for life; offer critiques of consumption; and emphasize the sharing of resources through social solidarity and cooperation rather than competition. The permaculture movement that is directly tied to FANJ's outreach and promotional efforts is a movement engaged in the spiritual transformation of deeply held values connecting human beings to one another and to the environment.

Major figures associated with FANJ sought to promote an ethic of responsibility towards the natural world by looking to earlier aspects of Cuban culture, such as the writings of a national hero, to argue that this ethic has always been a part of Cuban culture. In the aftermath of the Special Period crisis and the challenges to the Revolution's moral vision for a "New Human", civil society and religious organizations are stepping in to present their visions for what Cuban society should look like. For example, Antonio Núñez Jiménez, the "extraordinary Cuban revolutionary, geographer, anthropologist, agricultural reformer, and writer" (Birnbaum and Fox 2014, p. 54) wrote about José Martí's love of nature. José Martí is a national hero who was instrumental in defining the vision of Cuba Libre, or independence from Spain and the United States (Pérez 2015, p. 113). In addition to Martí's political writings, however, Martí is also known for his poetry and prose about human beings and their relationship to the natural world. In an 1882 publication in Caracas, for example, Martí wrote of the forest: "the forest brings reason and faith back to man, and it is the perpetual youth. The forest gladdens, like a good deed. Nature inspires, cures, consoles, and prepares the virtue of man" (Jiménez 1998, p. 385). In 1980, Jiménez embarked on a Campismo Popular (popular camping) program to "awaken a love of nature, of flora and fauna and the fight to preserve them" (Jiménez 1998, p. 514; Stricker 2007, p. 115). Permaculture was part of this vision of awakening a love of nature in individuals through its ethical and moral principles.

Although the Cuban state has promoted the use of sustainable methods of agricultural production in Cuba's environmental framework law (Stricker 2007, p. 43), some activists emphasized during interviews that there was still a long road ahead in terms of convincing individuals at the grassroots level to embrace an ethic of environmental awareness and love of nature. This seemed to be a notable challenge within the capital city of Havana, where Cuban youth are increasingly influenced by factors such as the role of mass media, new technologies, and the challenges of work opportunities that do not match their qualifications (Domínguez 2015, p. 384).

Leticia explained that FANJ is trying to promote a cambio de mentalidad among the Cuban youths who are associating farming and growing food with poverty. With recent changes in the availability of public Wi-Fi hotspots, cell phones, and computers, Leticia noted a concern about youth being "too taken by technology" (personal communication, 3 May 2016). Encouraging the development of a love of nature and the Earth is a central part of permaculture ethics and spirituality, so FANJ is working through its networks of national leaders and promotors to work specifically with Cuban youth and couples in these efforts to promote an environmental consciousness. The Centro Cristiano de Servicio y Capacitación "B.G. Lavastida" (hereafter "the Centro"), for example, is an ecumenical organization in Santiago dedicated to the promotion of healthy communities and ecosystems through its social engagement and outreach efforts. In its Training Program, the Centro has an area dedicated to issues that Cuban youth face today. Within all of its particular programs, including the promotion of permaculture, the Centro is actively working to engage with young people in an effort to address their material and spiritual needs.

Tony, a young man in the city of Sancti Spíritus who became exposed to permaculture through his wife, admitted that at first he associated the idea of permaculture with "work in the countryside". However, after learning more about it, Tony came to see permaculture as more than just planting food: "permaculture is holistic; you can apply it in all areas of your life. I started to learn and have a consciousness about the harm that one sometimes does to the planet, that in the end it's the home that unites us because we live here. If something happens to the planet, one way or another it's going to happen to us" (personal communication, 16 March 2016). In stating that harm to the planet harms human beings as well, Tony illustrated a theme heard frequently during qualitative interviews: human 
beings are in an interdependent relationship with the natural world, and if you take care of the Earth you are also taking care of yourself because you are dependent upon the Earth for life and sustenance.

Juan Manuel echoed this theme when discussing the first permaculture ethical principle of caring for the Earth; he argued that "there has to be a social change" when it comes to caring for the soil, because using chemicals will harm the soil, create more nitrogen in the soil, and ultimately create dead zones in the Gulf of Mexico. "The only way of producing a change is through the consciousness of people, from the consumer to the producer. It has to change" (personal communication, 9 March 2016). This cambio de mentalidad, or "change of mentality" is linked to a critique of consumption that is an integral part of the ethical messages within Cuban permaculture.

For Cuban activists, permaculture provides a critique of overconsumption that can be found within both environmental movements and religious traditions. It does this in two ways. First, it dismisses the notion that human beings are somehow separate from nature and that nature has value simply because of what it can provide for humans. Juan Manuel made this clear during his interview on 9 March 2016: "Some religious things say that humans have the right of stewardship [over the Earth]. I think that it's not even stewardship; we are a part of and connected to all the other animals that also have their rights". Oscar, who maintains a large permaculture system in Santiago of over 26 hectares (64 acres), made a similar statement: "the human being is one more part of the system ... the banana leaf fulfills its function within the system, right? We all fulfill a role within the system. I'm one more element within this system, me and my family are one more [element]" (personal communication, 30 March 2016). Oscar and Juan Manuel were emphasizing a key theme within Cuban permaculture: interdependence, or the web of relationships between elements within an ecosystem.

Second, Cuban permaculture provides a critique of overconsumption based upon its spirituality that emphasizes the common good. This spirituality highlights the need for social and ecological justice, where human beings and the natural environment have intrinsic value apart from the material goods that they can produce. From an ecological perspective, this integrated form of development utilizes the principles within permaculture design, such as catching and reusing energy, minimizing the use of external inputs within a system, composting, and recycling. From a spiritual and moral perspective, Cuban permaculture critiques visions of development that focus predominantly on the pursuit of individual wealth and the accumulation of material things, and there is an explicit emphasis on sharing whatever one has if someone is in need. Leidis, who works with the Centro in Santiago, pointed out that the third ethical principal of permaculture is the sharing of excess resources. In Cuba, however, excess resources are few and far between. So Cuban permaculturalists take a broader view of what constitutes a resource. Leidis mentioned that there would be many days where her husband Gabriel would say, "OK. Let's utilize two of the hours that we have in the day to go and work" in order to help out someone else (personal communication, 26 March 2016).

Leticia explained it this way: taking the permaculture design course not only taught them to create a physical permaculture system tied to their house; "we also designed and redesigned our lives, our family relationships, our human relationships, our relationships with the community". When discussing the second major principle of permaculture (Care for People), for example, Leticia argued that this principle "goes together with taking care of the spirit", of caring for not only the planting of healthy food, but caring for how people fundamentally relate to the natural world and to one another. When discussing the permaculture principle of taking care of others, she said that "it goes very well with taking care of the spirit, of taking care of not just 'I plant healthy, I eat healthy, and I keep myself healthy,' but also I relate in a healthy way with my partner, I relate in a healthy way with my children; I try to live happy, I try to prioritize the things that bring me happiness, that bring me well-being, that give me spiritual happiness. And so, I keep myself psychologically and spiritually healthy, and I keep my family healthy" (personal communication, 3 May 2016). This holistic view of spirituality within Cuban permaculture underscores the idea that the movement has a broader meaning beyond the planting of organic food, although it includes this dimension as part of its principles. 
Leticia also emphasized that one of the main principles within permaculture is collaboration rather than competition, along with valuing "the marginal". This can mean valuing people on the "margins" of society that need aid, such as those with psychiatric and mental health conditions (personal communication, 3 May 2016). Leticia also emphasized the importance of promoting ecological literacy among Cuban youth, and she noted that primary school teachers have requested visits to permaculture systems "so that the children can see water collection, see the compost, see the vermiculture, so that they can learn to view the soil as a living organism that one has to take care of" (personal communication, 3 May 2016). This process of learning to view the soil as a "living organism" illustrates the process of a change of consciousness within Cuban permaculture, where individuals learn to view and to live with the natural world in a different way.

Marieta, a Baptist in Santiago who also worked with the Centro, discussed how she has utilized her permaculture system as an opportunity to meet the spiritual and material needs of community members (personal communication, 29 March 2106). Marieta named her system "El Amor Construye" (Love Builds) because she and her husband have used the space as an opportunity to listen to and help women who are victims of violence. For Cuban permaculturalists, the ethics and values of the movement are tied to an emphasis on nonviolence towards other humans and the natural environment. Marieta has promoted social welfare programs and community outreach in other areas as well; she has helped youth "integrate into Cuban society" through workshops on José Martí in her permaculture system, and has hosted courses on nutrition and food conservation in an effort to encourage community members to eat healthy foods and preserve them during moments when they might not have access to food.

By emphasizing the development of at least some level of self-sufficiency, the permaculture movement in Cuba does not gloss over individual autonomy and creativity; in fact, one of the striking things I noted during fieldwork was the personal naming of individual permaculture systems to reflect individual creativity and, frequently, connections to friends and family. However, permaculture systems in Cuba are never created and maintained in total isolation. Individuals work on each other's systems in order to share knowledge and resources; they come together during encuentros (meetings) of activists from across the island through the work of FANJ; they share seeds with one another during these encuentros; and they rely upon one another in a tight-knit network of mutual aid and social solidarity. Marieta and other permaculture activists I interviewed emphasized that "we permaculturalists, we feel like a big family, like siblings. We love each other" (personal communication, 29 March 2016). Cuban permaculture also enlarges the definition of community and emphasizes the need for a fundamental perceptual shift in how individuals see themselves in relationship to the natural world and other people. It also focuses on a new way of living and designing one's life.

\section{Cuban Permaculture, Spirituality, and Social Solidarity}

An explicit emphasis on cooperation, social solidarity, and an expanded definition of community that includes the natural world has played an important role in the expansion of the permaculture movement in Cuba. As Birnbaum and Fox (2014, p. 55) note, the promotion of permaculture through FANJ has been deeply embedded within local communities and social movements. Some of these movements include religious groups and ecumenical centers. Through the training of local promotors, FANJ has networked directly with the Centro in Santiago. The Centro, founded by Pastor Elmer Lavastida Alfonso and his wife, the Reverend Gisela Pérez Muñiz, also has social welfare programs dedicated to permaculture, agroecology, food preservation, ecotheology, youth services, and caring for individuals with HIV / AIDS. Pastor Alfonso is the son of Bartolomé G. Lavastida-Díaz, founder of the Los Pinos Nuevos Bible School. The Los Pinos Nuevos Bible School started out as a nondenominational seminary, but today it is one of the largest denominations in Cuba and is considered the only national Protestant denomination (Esqueda 2007, pp. 18-19).

For promotors of permaculture who work with the Centro, the movement serves a vital social function: it encourages the formation of strong bonds of family and social solidarity through a network 
of activists who share knowledge, resources, and their time and energy with one another. Heidi, who works with the Centro, stated during an interview on 28 March 2018 that a "spirituality" of solidarity and respect between individuals has been created within permaculture groups "because we have spaces where everyone comes together. It doesn't matter if you have food production in your system and I don't. It doesn't matter; all of us are under the common good (personal communication, 28 March 2016). This notion of a "common good" is indicative not only of the ethics and spirituality within permaculture, but of values that have been particularly important within specific Cuban contexts and geographical regions. The eastern provinces of Cuba, for example, are prone to additional natural disasters and issues beyond the general issues of the island as a whole. Permaculture activists tied to the Centro emphasized that the region of Santiago was facing water shortages and droughts that made the collection and filtration of water an essential feature of permaculture systems in the area.

According to a March 2016 website from Oxfam, the eastern regions of Santiago de Cuba, Guantanamo, and Baracoa have also been hit with a high frequency of seismic activity since January of 2016 (Oxfam 2016). Nilda, a permaculture activist who works with the Centro as a collaborator with the Food Preservation Program, showed me areas of her system that had been damaged during the last earthquake in January of 2016. Nilda also noted that Hurricane Sandy "had destroyed everything" in 2012, including her house (personal communication, 29 March 2016). Thanks to the knowledge that she had gained through permaculture, however, Nilda was better prepared because "the permaculturalists, we have seeds saved" (personal communication, 29 March 2016). Saving and sharing seeds with one another has not only encouraged the development of social solidarity within the Cuban permaculture movement; it has made it easier for permaculturalists to start growing food again after natural disasters.

The main ethical principles of permaculture (Caring for the Earth, Caring for People, and Sharing Resources) have served vital social and spiritual functions within the Cuban context for people from a variety of backgrounds. In terms of the social function of Cuban permaculture, the movement has (1) helped individuals collect, share, and save seeds in order to increase biodiversity within permaculture systems and encourage food security; and (2) created networks of permaculture activists who know one another and can help each other during difficult moments. These networks serve important functions within a context of material scarcity since the fall of the Soviet Union. The spiritual functions of Cuban permaculture are closely linked to the social functions of the movement, because Cuba's post-soviet cultural, political, and social changes have helped create the conditions for a search for spiritual fulfillment within society. The Cuban permaculture movement has created a spirituality that promotes a change of individual consciousness on the one hand, while also highlighting a social analysis that critiques overconsumption and the redistribution of resources on the other. This spirituality emphasizes themes of the common good and social solidarity and unites activists of different backgrounds and relationships to organized religion.

\section{Conclusions}

Social networks that address both the material and the spiritual needs of individuals have increased in recent years in Cuba, particularly since the fall of the Soviet Bloc. As Crahan (2015) notes, there are several reasons for this. One of them involves the fact that the state's ability to ensure basic needs has decreased, and religious and civil society organizations are stepping in to meet these needs. Second (and this point might be related to the first), there has been an increase in the "capacity, skills, and motivation to organize outside the realm of the state" (Crahan 2015, p. 92). As a holistic movement that addresses spiritual as well as material concerns, permaculture arrived in Cuba in the early 1990s and was able to spread because of these changes. When Cuban permaculture activists spoke of the need for a cambio de mentalidad (change of mentality), they were also pointing to this shift towards the development of an ecological consciousness. This change of mentality is rooted within critiques of overconsumption of the Earth's resources, as well as a critique of Cartesian dualism that separates human beings from nature. 
Interviews with permaculture activists in this case study indicate that individuals are attracted to the permaculture movement because it is fulfilling an important social and spiritual function within the post-Soviet context. The close friendships of Cuban permaculturalists have contributed to the growth of the movement because individuals know that they are never alone; they are part of something bigger than themselves, and this contributes to a holistic vision of sustainability. Johnston (2013, p. 24) notes that it is helpful to separate out the idea of sustainability into several dimensions: the ecological dimension, where the realm of human activities is ecologically sustainable; the equity/equality dimensions, where resources are distributed fairly; and the efficiency dimension, where resources are allocated according to the first and second dimensions. All three of these dimensions are present within the Cuban permaculture movement, and qualitative interviews with activists indicate that individuals have been attracted to permaculture because these dimensions are addressed in a holistic way through social networks of solidarity.

Taylor (2010) identified, through numerous examples that included nature writers, radical environmentalists, scientists, and permaculture, examples of dark green religion. He acknowledges that although the momentum from trends of ecological destruction seems stronger than the movements that have arisen to resist them, dark green religion is capable of moving and influencing individuals because of its compelling stories and narratives (Taylor 2010, p. 219). The wide range of examples that Taylor provides are useful because they can help scholars broaden definitions of religion to include religious-resembling movements, rituals, beliefs, and practices. However, the relationships between religious-like movements that encourage the reverent care of nature and civil society deserve a deeper analysis.

Qualitative interviews with activists reveal that the Cuban permaculture movement contains multiple approaches to defining religion, spirituality, and connections to the sacred. Some of these approaches are tied to institutionalized religions such as varieties of Christianity, while others are connected to nature-based spiritualities and non-institutionalized religions. They include (1) perspectives that highlight the intrinsic value of non-human nature; (2) Creation Care narratives within institutionalized religions such as Christianity; (3) spiritualities connected to social welfare and a focus on the common good; and (4) holistic definitions of spirituality that focus on the concept of interdependence between all living things. Within some qualitative interviews, activists combined two or more of these different approaches as they described their relationships to permaculture, how they interpreted permaculture's ethical principles, and why they became involved with the movement.

Cuban permaculture is a religious-resembling movement that encourages the kind of change of consciousness that Taylor discusses within nature spiritualities and dark green religion. In addition to encouraging a cambio de mentalidad, however, it also provides a social critique of modern consumption and industrialized agricultural methods. For Taylor, dark green religion is rapidly growing and is as widespread as most traditional religions. However, "it has neither a priesthood nor institutions officially devoted to its promotion", even though it does have "institutional manifestations" (Taylor 2010, p. 217). In the Cuban case, however, permaculture does have an institution that is officially devoted to its promotion. FANJ, an NGO that has collaborated with multiple state institutions, international organizations, and religious groups, has played a fundamental role in the spread and promotion of the movement. This has created a spirituality that allows flexibility in perspectives about nature as sacred, critiques of consumption, a focus on social solidarity, and a view of the "New Cuban" that involves deep and affective bonds between human beings and the natural world. The Cuban case can encourage scholars to examine further the role that social and state institutions are playing within nature-based spiritualties throughout the world.

Funding: This research was funded by a 2015 grant from the Center for Excellence in the Arts and Humanities at Iowa State University.

Acknowledgments: The author is grateful to Eleanor Finnegan for commenting on an earlier draft of this article. The author also wishes to thank the Center for Excellence in the Arts and Humanities at Iowa State University for 
a research grant in support of this work, and the Fundación Antonio Núñez Jiménez de la Naturaleza y Hombre for organizing and providing visa sponsorship during fieldwork.

Conflicts of Interest: The author declares no conflict of interest.

\section{References}

Altieri, Miguel A., and Fernando R. Funes-Monzote. 2012. The Paradox of Cuban Agriculture. Monthly Review, January 1.

Birnbaum, Juliana, and Louis Fox. 2014. Sustainable Revolution: Permaculture in Ecovillages, Urban Farms, and Communities Worldwide. Berkeley: North Atlantic Books.

Blum, Denise F. 2011. Cuban Youth and Revolutionary Values: Educating the New Socialist Citizen. Austin: University of Texas Press.

Crahan, Margaret. 2009. Cuba. In Religious Freedom and Evangelization in Latin America: The Challenge of Religious Pluralism. Edited by Paul E. Sigmund. Eugene: Wipf and Stock, pp. 87-112.

Crahan, Margaret. 2015. Religion and Civil Society in Cuba, 1959-2013. In A Contemporary Cuba Reader. Edited by Philip Brenner. Lanham: Rowman and Littlefield, pp. 89-98.

Cruz, María Caridad, Roberto Sánchez Medina, and Carmen Cabrera. 2006. Permacultura Criolla. La Habana: Fundación Antonio Núñez Jiménez de la Naturaleza y Hombre.

Domínguez, María Isabel. Cuban Youth: From the "Special Period" to the "Updating" of the Economic and Social Model. In A Contemporary Cuba Reader. Edited by Philip Brenner; Lanham: Rowman and Littlefield, pp. 381-88.

Esqueda, Octavio J. 2007. Theological Higher Education in Cuba: Part 2: Origins and Ministry of Protestant Seminaries. Christian Higher Education 6: 15-28. [CrossRef]

Funes-Monzote, Fernando R. Cuba: A National-Level Experiment in Conversion. In The Conversion to Sustainable Agriculture: Principles, Processes, and Practices. Edited by Martha Rosemeyer and Stephen R. Gliessman. Boca Raton: CRC Press, pp. 205-37.

Gibson-Graham, J. K., and Gerda Roelvink. 2011. The Nitty Gritty of Creating Alternative Economies. Social Alternatives 30: 29-33.

Gold, Marina. 2015. People and State in Socialist Cuba: Ideas and Practices of Revolution. New York: Palgrave Macmillan.

Harnecker, Camila Piñeiro. 2015. Cuba's New Socialism: Different Visions Shaping Current Changes. In $A$ Contemporary Cuba Reader. Edited by Philip Brenner. Lanham: Rowman and Littlefield, pp. 49-58.

Holmgren, David. 2002. Permaculture: Principles and Pathways beyond Sustainability. Hepburn: Holmgren Design Services.

Holt-Giménez, Eric. 2006. Campesino a Campesino: Voices from Latin America's Farmer to Farmer Movement for Sustainable Agriculture. Oakland: Food First Books.

Jiménez, Antonio Núñez. 1998. Hacia una Cultura de la Naturaleza. Havana: Fundación de la Naturaleza y Hombre. Johnson, Christian. 2017. Three Global Lessons Learned from Cuban History and Nonprofits. Forbes, September 14. Johnston, Lucas F. 2013. Religion and Sustainability: Social Movements and the Politics of the Environment. Sheffield: Equinox. Kocur, Zoya. 2016. Sparks of Civil Society in Cuba: Afro-Cuban Cultural Production, Artistic Interventions, and the Struggle for a New Public Sphere. In Handbook of Contemporary Cuba: Economy Politics, Civil Society, and Globalization. Edited by Mauricio A. Font and Carlos Riobó. London: New York: Routledge, pp. $228-42$.

Koont, Sinan. 2015. Sustainable Urban Agriculture in Cuba. Gainesville: University Press of Florida.

Leopold, Aldo. 1987. The Land Ethic. In A Sand County Almanac, and Sketches Here and There. New York: Oxford University Press. First published 1949.

Oxfam. 2016. The Earth is Shaking All across Cuba, Not Only in Havana. Oxfam, March 22.

Pérez, Louis A. 2015. Cuba: Between Reform and Revolution. New York: Oxford University Press.

Reguant, Ariana H. 2009. Writing in the Special Period: An Introduction. In Cuba in the Special Period: Culture and Ideology in the 1990s. Edited by Ariana Reguant. New York: Palgrave Macmillan.

Scarpaci, Joseph L. 2002. Havana: The Dynamics of Local Executive Power. In Capital City Politics in Latin America: Democratization and Empowerment. Edited by David J. Myers and Henry A. Dietz. Boulder: London: Lynne Rienner Publishers.

Sosa, Braulio Machín, Adilén María Roque Jaime, Dana Rocío Ávila Lozano, and Peter Michael Rosset. 2013. Agroecological Revolution: The Farmer-to-Farmer Movement in Cuba. Havana: National Association of Small Farmers. 
Stricker, Pamela. 2007. Toward a Culture of Nature: Environmental Policy and Sustainable Development in Cuba. Lanham: Lexington Books.

Taylor, Bron R. 2010. Dark Green Religion: Nature Spirituality and the Planetary Future. Berkeley: University of California Press.

Williams, Justine MacKesson. 2017. Building Community Capacity for Food and Agricultural Justice: Lessons from the Cuban Permaculture Movement. In Food Justice in US and Global Contexts: Bringing Theory and Practice Together. Edited by Ian Werkheiser and Zachary Piso. Berlin: Springer, Volume 24, pp. 31-50.

(c) ( ) 